\title{
MENGGUNAKAN MEDIA BONEKA TANGAN UNTUK MENINGKATAN KETERAMPILAN DALAM BERDONGENG SISWA KELAS IX-5 SMP NEGERI 4 TEBING TINGGI
}

\author{
Gloria Samosir \\ Surel: gloriasamosir98@gmail.com
}

\begin{abstract}
This study aims to improve the storytelling skills of students of Class IX-5 of SMP Negeri 4 Tebing Tinggi using hand puppet media. This research is a classroom action research conducted at SMP Negeri 4 Tebing Tinggi. The research subjects were Class IX-5 students consisting of 36 students. This study consisted of two cycles. Each cycle consists of four stages, namely planning, carrying out actions, observations, reflections. The research instruments in the form of field notes, observation sheets, questionnaires, and assessment sheets told stories. Product upgrading can be seen from the increase in the score of students' storytelling results in each cycle. The average ability of students to tell stories before the action is categorized as lacking. However, after the implementation of the action for two cycles, the average ability of students in storytelling became a good category. Improved product quality / results can be seen from the comparison of the average score of storytelling students in the pre-action stage until after the Cycle II action. The average score of students in the preaction stage was 19.17, in Cycle I it increased to 23.03, and in Cycle II it increased again to 25.89 .
\end{abstract}

Keywords: Hand Puppet Media, Storytelling Skills

\begin{abstract}
ABSTRAK
Penelitian ini bertujuan untuk meningkatkan keterampilan bercerita siswa Kelas IX-5 SMP Negeri 4 Tebing Tinggi dengan menggunakan media boneka tangan. Penelitian ini merupakan penelitian tindakan kelas yang dilakukan di SMP Negeri 4 Tebing Tinggi. Subjek penelitian adalah siswa Kelas IX-5 yang terdiri dari 36 siswa. Penelitian ini terdiri dari dua siklus. Setiap siklus terdiri dari empat tahap, yaitu perencanaan, pelaksanaan tindakan, pengamatan, refleksi. Instrumen penelitian berupa catatan lapangan, lembar pengamatan, angket, dan lembar penilaian bercerita. Peningkatan secara produk dapat dilihat dari peningkatan skor hasil bercerita siswa pada setiap siklus. Kemampuan rata-rata siswa dalam bercerita sebelum adanya tindakan berkategori kurang. Namun, setelah implementasi tindakan selama dua siklus, kemampuan rata-rata siswa dalam bercerita menjadi kategori baik. Peningkatan kualitas produk/hasil dapat dilihat dari perbandingan skor rata-rata bercerita siswa pada tahap pratindakan sampai pasca tindakan Siklus II. Skor rata-rata siswa pada tahap pratindakan sebesar 19,17, pada Siklus I meningkat menjadi 23,03, dan pada Siklus II meningkat lagi menjadi 25,89.
\end{abstract}

Kata Kunci: Media Boneka Tangan, Keterampilan Bercerita 



\section{PENDAHULUAN}

Kehidupan manusia tidak dapat dilepaskan dari bahasa. Bahasa merupakan sarana untuk berkomunikasi antarmanusia. Bahasa sebagai alat komunikasi ini dalam rangka memenuhi sifat manusia sebagai makhluk sosial yang perlu berinteraksi dengan sesama manusia. Sejalan dengan perkembangan ilmu pengetahuan dan teknologi, manusia dituntut untuk mempunyai kemampuan berbahasa yang baik. Keterampilan berbahasa mempunyai empat komponen, yaitu keterampilan menyimak (listening skills), keterampilan berbicara (speaking skills), keterampilan membaca (reading skills), dan keterampilan menulis (writing skills) (Tarigan, 2008:1). Setiap keterampilan mempunyai hubungan yang erat dengan proses-proses berpikir yang mendasari bahasa. Bahasa seseorang mencerminkan pikirannya. Semakin terampil seseorang berbahasa, semakin cerah dan jelas pula jalan pemikirannya. Keterampilan hanya dapat diperoleh dan dikuasai dengan jalan praktik dan banyak latihan. Berbicara merupakan salah satu aspek keterampilan berbahasa yang bersifat produktif, artinya suatu kemampuan yang dimiliki seseorang untuk menyampaikan gagasan, pikiran atau perasaan sehingga gagasan-gagasan yang ada dalam pikiran pembicara dapat dipahami orang lain. Berbicara berarti mengemukakan ide atau pesan lisan secara aktif melalui lambang-lambang bunyiagar terjadi kegiatan komunikasi antara penutur dan mitra tutur.

Memang setiap orang dikodratkan untuk bisa berbicara atau berkomunikasi secara lisan, tetapi tidak semua memiliki keterampilan untuk berbicara secara baik dan benar. Kemampuan berkomunikasi, berbicara dan berbahasa dapat diperoleh di mana saja dan kapan saja. Mulai dari lingkungan keluarga kecil, keluarga besar, lingkungan sekitar tempat tinggal, dan sekolah. Dengan kata lain, dalam kehidupan sehari-hari siswa selalu melakukan dan dihadapkan pada kegiatan berbicara. Namun pada kenyataannya pembelajaran berbicara di sekolah-sekolah belum bisa dikatakan maksimal, sehingga keterampilan siswa dalam bercerita pun masih rendah.Bercerita merupakan salah satu kebiasaan masyarakat sejak dahulu sampai sekarang. Pada umumnya manusia senang melakukan kegiatan bercerita, dari usia anak-anak sampai dewasa. Bercerita dapat dipahami sebagai suatu tuturan yang memaparkan/ menjelaskan bagaimana terjadinya suatu hal, peristiwa, dan kejadian, baik yang dialami sendiri maupun orang lain. Seseorang dapat bertukar pengalaman, perasaan, informasi dan keinginannya melalui kegiatan bercerita. Dengan demikian, kegiatan berbicara khususnya bercerita dapat membangun hubungan mental, emosional antara satu individu dengan individu lain.

Pelaksanaan bercerita harus menguasai bahan/ ide cerita, penguasaan bahasa, pemilihan bahasa, keberanian, ketenangan, kesanggupan menyampaikan ide 
dengan lancar dan teratur sehingga mampu dan terampil dalam bercerita. Keterampilan bercerita tidak hanya diperoleh begitu saja, tetapi harus dipelajari dan dilatih.Menurut hasil wawancara pada tanggal 7 Februari 2016 antara peneliti dengan guru mata pelajaran Bahasa Indonesia Kelas IX SMP Negeri 4 Tebing Tinggi, diperoleh informasi bahwa dalam kegiatan bercerita, prestasi siswa tergolong rendah terutama pada Kelas IX-5 SMP Negeri 4 Tebing Tinggi. Pemilihan lokasi penelitian didasarkan pada permasalahan yang muncul di SMP Negeri 4 Tebing Tinggi. Hal ini didasarkan pada fakta di lapangan yang menyebutkan ada beberapa hal yang melatarbelakangi masalah tersebut.

Pembelajaran bercerita tidak dilakukan secara serius dan beranggapan bahwa bercerita merupakan bagian sepele yang sering dilakukan oleh siapa saja sejak usia balita. Padahal pada kenyataannya di lapangan, masih banyak siswa kurang mampu mengekspresikan diri melalui kegiatan bercerita. Ketika siswa diminta bercerita di depan kelas, siswa seringkali tidak mempunyai ide, malu, grogi sehingga kata yang diucapkan menjadi tersendat-sendat/ diulang-ulang. Hal ini disebabkan oleh kesulitan siswa dalam praktik bercerita di antaranya karena faktor dalam diri siswa menjadi kurang jelas dan siswa kurang memapu mengorganisasikan perkataannya pada saat bercerita. Dengan demikian, dapat diidentifikasi bahwa keterampilan bercerita siswa masih rendah.
Keterampilan bercerita akan berhasil dan meningkat dengan menggunakan media pembelajaran yang sesuai. Kurangnya pemanfaatan media dalam pembelajaran membuat siswa menjadi kurang aktif dan kreatif. Dalam pembelajaran sebaiknya guru memberdayakan media pembelajaran yang ada serta sesuai dengan metode pembelajaran yang diterapkan. Berdasarkan pada Kurikulum mata pelajaran Bahasa Indonesia Kelas IX SMP Negeri 4 Tebing Tinggi, khususnya standar kompetensi berbicara ada beberapa kompetensi dasar, yang salah satu di antaranya adalah bercerita dengan alat peraga. Dalam kompetensi ini, siswa diharapkan dapat bercerita dengan alat peraga.Cara mengatasi hal tersebut, guru hendaknya dapat menggunakan alternatif pembelajaran dengan media. Media yang dirasa tepat untuk mengatasi masalah pada siswa Kelas IX-5 SMP Negeri 4 Tebing Tinggi adalah menggunakan media boneka tangan, didasarkan pada beberapa alasan. Pertama menurut Raemiza media boneka tangan merupakan media yang paling efektif untuk pengajaran dalam mengembangkan perbendaharaan kata, melatih diri untuk mendengarkan dan berbicara.

$\begin{array}{cr}\text { Penggunaan } & \text { boneka } \\ \text { tangan dimaksudkan untuk }\end{array}$ memotivasi siswa supaya berpikir kreatif. Siswa dapat mengorganisasikan ide-ide untuk bercerita yang ditemukan dari sebuah tokoh boneka tangan, lalu dituangkan secara bebas dengan kata-kata sendiri. Kedua, 
pemilihan boneka tangan juga di latarbelakangi oleh kedekatan anak-anak dengan boneka. Kenyataan ini akhirnya dimanfaatkan sebagai motivasi dari sisi minat siswa yang diharapkan dapat mengoptimalkan hasil belajar.

Media boneka tangan dipilih untuk meningkatkan keterampilan bercerita karena dalam bercerita siswa harus mempunyai ide/bahan cerita, keberanian, penguasaan bahasa, dan ekspresi. Media boneka tangan cocok digunakan dalam pembelajaran keterampilan bercerita. Berdasarkan wawancara pada tanggal 7 Februari 2016 antara peneliti dan kolaborator guru Bahasa Indonesia media boneka tangan belum pernah diterapkan untuk meningkatkan keterampilan bercerita siswa.Penerapan media boneka tangan dapat menjadi alternatif sekaligus inovasi bagi guru dalam pembelajaran tentang bercerita agar semakin meningkat. Oleh karena itu, untuk mengatasi permasalahan yang ada di SMP Negeri 4 Tebing Tinggi yang berkaitan dengan meningkatkan keterampilan bercerita, maka peneliti menggunakan media boneka tangan sebagai media pembelajaran.

Berdasarkan rumusan masalah di atas, maka penelitian ini mempunyai tujuan yang ingin dicapai. Adapun tujuan yang ingin dicapai dalam penelitian ini adalah sebagai berikut: Mendeskripsikan proses peningkatan pembelajaran bercerita siswa Kelas IX-5 SMP Negeri 4 Tebing Tinggi dengan media pembelajaran boneka tangan?

\section{METODE PENELITIAN}

Setting tempat yaitu di lokasi mana peneliti melakukan penelitian. Lokasi penelitian ini dilaksanakan di SMP Negeri 4 Tebing Tinggi, yang secara geografis sekolah ini terletak di Jln. D. I. Panjaitan, Kecamatan Tebing Tinggi Kota, Kota Tebing Tinggi. Peneliti memilih tempat penelitian di SMP Negeri 4 Tebing Tinggi karena SMP tersebut belum pernah dilakukan penelitian dengan menggunakan media boneka tangan dalam pembelajaran keterampilan bercerita.

Penelitian tindakan kelas dilaksanakan mulai bulan JuliAgustus 2016. Pelaksanaan penelitian menyesuaikan dengan kalender pendidikan. Adapun pelaksanaan tindakan disesuaikan dengan jadwal pelajaran Bahasa Indonesia Kelas IX-5 SMP Negeri 4 Tebing Tinggi. Jadwal pelaksanaan tindakan pada saat penelitian dibuat berdasarkan kesepakatan guru kolaborator.

Teknik yang digunakan dalam penelitian ini adalah deskriptif kualitatif. Teknik ini digunakan dalam rangka mendeskripsikan kemampuan berbicara siswa sebelum dan sesudah mendapat tindakan. Teknik ini dibagi dua, yaitu analisis proses dan analisis produk. Analisis data secara proses diambil pada waktu pembelajaran keterampilan bercerita menggunakan media boneka tangan. Analisis produk diambil dari hasil penilaian 
praktik bercerita siswa.

\section{HASIL PENELITIAN DAN PEMBAHASAN}

Mengenai hasil penelitian sebagai jawaban atas rumusan masalah yang diajukan. Sebelum hasil penelitian dipaparkan akan diuraikan terlebih dahulu mengenai kondisi awal kemampuan siswa (pratindakan) keterampilan bercerita Kelas IX-5 SMP Negeri 4 Tebing Tinggi. Dengan demikian, secara urut bab ini akan menjelaskan tentang (1) kondisi awal keterampilan bercerita siswa Kelas IX-5 SMP Negeri 4 Tebing Tinggi, (2) pelaksanaan tindakan seerta hasil penelitian, dan (3) pembahasan hasil penelitian. Penelitian tindakan dilakukan dalam 2 siklus 4 tahap pada masing-masing siklus. Tahapan tersebut meliputi kegiatan: pada tahap perencanaan, tahap pelaksanaan tindakan, pengamatan, dan refleksi. Hasil angket yang diisi oleh siswa Kelas IX-5 SMP Negeri 4 Tebing Tinggiterkait dengan perlu atau tidaknya media pembelajaran yang digunakanuntuk mendukung keberhasilan pembelajaran keterampilan bercerita. Sebanyak31 siswa menyatakan perlu adanya media pembelajaran yang diharapkan bisamendukung keberhasilan pembelajaran keterampilan bercerita.

$$
\text { Berdasarkan hasil }
$$

pengamatan peneliti dan hasil angket dapat disimpulkansecara keseluruhan bahwa sebagian besar siswa kurang berani tampil bercerita. Hal ini disebabkan karena siswa malu, grogi, tidak bisa bercerita dan takut salahjika bercerita di depan kelas. Menurut hasil tes yang dilakukan pada saat surveiawal diketahui bahwa keterampilan bercerita siswa Kelas IX-5 SMP Negeri 4 Tebing Tinggi masih tergolong rendah, karena belum mencapai bataskelulusan sekolah (rata-rata 65). Keterampilan awal dilihat dari hasil tes pratindakan awal yang dilakukan sebelum dikenai tindakan. Skor rata-rata kelas tiap aspek untuk mengetahui keterampilan bercerita maka setiap aspek tersebut dihitung.

\section{SIKLUS I}

Siklus I disimpulkan bahwa kemampuan bercerita siswa mengalami peningkatan, pada pratindakan jumlah skor yaitu 19,17 meningkat menjadi 23,03 siklus I. Peningkatan pada setiap aspek penilaian bercerita, mulai dari aspek yang mengalami peningkatan paling tinggi sampai yang paling rendah, yaitu kelancaran, sikap penghayatan cerita, volume suara, pelafalan, keterampilan mengembangkan ide, ketepatan ucapan dan pilihan kata. Terjadi peningkatan pada aspek bercerita tidak terlepas dari peran media boneka tangan yang dapat memacu siswa untuk terampil bercerita. Keadaan tersebut tidak terlepas dari pengaruh pembelajaran dengan menggunakan media boneka tangan yang bertujuan untuk memotivasi siswadalam keterampilan bercerita sehingga siswa mampu dan berani bercerita di depan kelas. Aspek keaktifan, perhatian dan kerjasama kelompok dalam pembelajaran belum maksimal sehingga perlu ditingkatkan lagi. Hal tersebut akan menjadi perbaikan untuk 
siklus selanjutnya.Secara produk, peningkatan keterampilan bercerita siswa dapat dilihat dari tes bercerita. Peningkatan skor dapat dilihat dari skor rata-rata kelas pratindakan ke siklus I yang meliputi peningkatan tiap-tiap aspeknya, peningkatan tersebut, yaitu (1) volume suara sebesar 0,50 , (2) pelafalan sebesar 0,75, (3) keterampilan mengembangkan ide sebesar 0,36, (4) sikap penghayatan cerita sebesar 0,47 , (5) kelancaran sebesar 0,81, (6) ketepatan ucapan sebesar 0,53, (7) pilihan kata sebesar 0,46.

Hasil yang didapatkan dari siklus I baik secara proses maupun produk telah menunjukkan peningkatan yang cukup baik walaupun masih kurang memuaskan, karena masih ada beberapa kendala yang dihadapi. Kendala tersebut adalah sebagai berikut:

a. Skor aspek ketepatan ucapan siswa perlu ditingkatkan lagi.

b. Pemilihan kata dalam merangkai cerita perlu ditingkatkan.

c. Skor peningkatan yang diperoleh masih kurang maksimal.

Refleksi yang dilakukan baik secara proses maupun secara produk serta kekurangan atau kendala terjadi selama siklus I menjadi dasar pelaksanaan siklus II, pada siklus II masih tetap menggunakan media boneka tangan.

\section{SIKLUS II}

$\begin{array}{lr}\text { Dapat } & \text { diketahui } \\ \text { peningkatan skor } & \text { aspek } \\ \text { pengamatan proses pembelajaran } \\ \text { keterampilan bercerita siswa }\end{array}$

menggunakan media boneka tangan yang telah dilakukan dari mulai pratindakan sebesar 12,67 dan setelah diberi tindakan maka siklus I meningkat menjadi 14,48 dan siklus II meningkat menjadi 16,53. Kenaikan skor rata-rata mulai dari pratindakan hingga siklus II dalah sebesar 3,86. Pada pascatindakan Siklus II peningkatan paling tinggi atau paling baik terjadi pada aspek minat siswa selama pelajaran, sedangkan aspek yang mengalami peningkatan paling kecil adalah aspek keaktifan siswa.Pada siklus II ini sudah lebih baik dan sesuai rencana dibandingkan dengan siklus sebelumnya. Siswa semakin aktif dalam pembelajaran dan siswa mengerjakan tugas dengan baik. Siswa memperhatikan serta konsentrasi dalam mengikuti pembelajran keterampilan bercerita. Selain itu, siswa juga berminat dan antusias mengembangkan tema, dan merangkai pokok-pokok cerita menjadi sebuah cerita yang menarik. Kerja sama timpun lebih kompak dibandingkan dengan siklus sebelumnya, mereka saling memberikan ide untuk merangkai cerita. peningkatan skor tes keterampilan bercerita siswa menggunakan media boneka tangan yang telah dilakukan dari mulai pratindakan sebesar 19,17 dan setelah diberi tindakan pada siklus I meningkat menjadi 23,03, dan siklus II meningkat menjadi 25,89. Kenaikan skor rata-rata mulai pratindakan hingga siklus II sebesar 6,72. Pada pascatindakan siklus II peningkatan paling tinggi atau paling baik terjadi pada aspek kelancaran, sedangkan aspek yang mengalami peningkatan paling 
kecil adalah aspek ketepatan ucapan.

\section{Pembahasan}

Penelitian tindakan kelas tentang peningkatan keterampilan bercerita dengan menggunakan media boneka tangan siswa Kelas IX-5 SMP Negeri 4 Tebing Tinggi dihentikan pada siklus II. Berdasarkan diskusi antara peneliti dengan guru kolaborator, penelitian ini mengalami keterbatasan waktu yaitu siswa harus melanjutkan materi pembelajaran yang lain agar tidak tertinggal dengan kelas yang lain dan pada saat penelitian khususnya pada siklus I dan II bersamaan dengan bulan puasa sehingga waktu pembelajaran akan terpotong jelang libur hari raya Idul Fitri. Selain itu, waktu yang diberikan kepada peneliti oleh pihak sekolah maksimal 9 kali pertemuan. Dengan demikian, penelitian dihentikan pada siklus II.

\section{SIMPULAN}

Simpulan mengenai hasil peningkatan yang terdapat dalam penelitian ini dapat dilihat dari uraian berikut:

a. Media Boneka Tangan dapat meningkatkan kualitas proses pembelajaran keterampilan bercerita siswa Kelas IX-5 SMP Negeri 4 Tebing Tinggi. Siswa mengalami perubahan perilaku (peningkatan) dalam pembelajaran. Peningkatan keterampilan bercerita siswa ditunjukkan oleh keaktifan siswa selama proses pembelajaran berlangsung, perhatian dan konsentrasi siswa dalam menyimak materi pelajaran yang disampaikan oleh guru, minat dan antusias siswa selama pembelajaran, pada pelajaran, keberanian siswa bercerita di depan kelas dan kerjasama kelompok sehingga dapat menciptakan pembelajaran yang menyenangkan, aktif dan kreatif.

b. Media Boneka Tangan dapat meningkatkan produk/hasil keterampilan bercerita siswa Kelas IX-5 SMP Negeri 4 Tebing Tinggi. Peningkatan kualitas produk/hasil dapat dilihat dari perbandingan skor rata-rata bercerita siswa pada tahap pratindakan dan pascatindakan Siklus II. Peningkatan tersebut ditandai dengan meningkatnya penguasaan aspek-aspek keterampilan bercerita seperti volume suara, pelafalan, mengembangkan ide, sikap penghayatan cerita, kelancaran, ketepatan ucapan, dan pilihan kata. Pada tahap pratindakan diperoleh skor rata-ratasebesar 19,17, pada siklus I meningkat menjadi 23,03, dan pada siklus II juga meningkat menjadi 25,89 . Dengan demikian, keterampilan bercerita siswa Kelas IX-5 SMP Negeri 4 Tebing Tinggi telah mengalami peningkatan baik secara proses maupun produk setelah diberi tindakan menggunakan media boneka tangan.

\section{DAFTAR RUJUKAN}

Arikunto, Suharsimi dkk. 2006. Penelitian Tindakan Kelas. Jakarta: Bumi Akasara 
Arsjad, G. Maidar dan Mukti. 1987. Pembinaan Kemampuan Berbicara Bahasa Indonesia. Jakarta: Erlangga.

Arsyad, Azhar. 2016. Media Pembelajaran. Jakarta: Raja Grafindo Persada.

Departemen Pendidikan Nasional. 2005. Kamus Besar Bahasa Indonesia. Jakarta: Balai Pustaka.

Kustandi dan Sutjipto. 2016. Media Pembelajaran Manual dan Digital. Jakarta: Ghalia Indonesia

Madya, Suwarsih. 2006. Teori dan Praktik Penelitian Tindakan. Bandung: Alfabeta.

Sadiman, Arief S, dkk. 2008. Media Pendidikan Pengertian, Pengembangan, dan Pemanfaatannya. Jakarta: PT. Raja Grafindo Persada.

Siswoyo,dkk. 2007. Ilmu Pendidikan. Yogyakarta: UNY Press.

Soeparno. $1980 . \quad M e d i a$ Pengajaran Bahasa. Yogyakarta: PT. Intan Pariwara.

Sudarmadji. 2010. Teknik Bercerita. Yogyakarta: PT. Kurnia Kalam Semesta.

Sudjana dan Rivai. 2010. Media Pengajaran. Bandung: Sinar Baru Algensido

Sudirman. 1992. Ilmu Pendidikan. Bandung: PT Remaja Rosdakarya. 